\title{
Piotr Szlaużys
}

DOI: $10.15290 /$ bth.2017.15.06

Wydział Historyczno-Socjologiczny

Uniwersytet w Białymstoku

\section{Lithuanians in the United States at the turn of the 19th and 20th centuries}

There are not many publications about the Lithuanians living in the United States at the turn of the nineteenth and twentieth centuries. Partly this situation results from the lack of recognition of Lithuanian Americans as a separate ethnic group at that time. The US Census Bureau did not report them as Lithuanians until after World War I because Lithuania did not exist as an independent country until 1918, and they were usually recorded as Russians, Poles, or Germans. The majority of Lithuanians coming to the United States in the second half of the nineteenth century had been peasants in their homeland. They had cultural backgrounds characteristic of their ethnic group, e.g. they spoke Lithuanian, were Catholics, and had distinct traditions. Still, most of them, as Victor Greene mentions, "had little or no feeling of membership in an ethnic group".

Lithuanian Americans started to be more conscious of their national identity at the end of the nineteenth century, when the number of Lithuanian immigrants sharply increased and their social and political organisations started to be established in the United States. Furthermore, starting from the 1880s, Lithuanian immigrants were more conscious of their self-identity before leaving their homeland, owing to the increasing popularity of the Lithuanian language and Catholic religion in response to the Russian authorities' harsh policy of Russification in the Lithuanians' native land, partitioned by the German Reich and Russia ${ }^{2}$.

Lithuanians emigrating to the United States mainly for economic reasons were hopeful that they could some time return to their independent homeland, where they could invest the money earned abroad and re-unite with their families. Their self-identity in the United States also increased because they realised that the

\footnotetext{
1 V. R. Greene, For God and Country: the Rise of Polish and Lithuanian Ethnic Consciousness in America, 1860-1910. Madison: State Historical Society of Wisconsin, 1975, p. 3.

2 J. Ochmański, Historia Litwy, Ossolineum 1990, p. 277.
} 
members of other American ethnic communities, who spoke different languages and had diverse cultural backgrounds, were usually integrated as communities. Their integration manifested in professing their own religion, learning their mother tongue, participating in cultural events, intermarrying or printing their own press. Other ethnic groups' tendency for integration led Lithuanian Americans to believe that they could also strengthen their cultural backgrounds. They were encouraged to cultivate their own ethnic values especially because they could unrestrictedly use their mother tongue and profess their ethnic cultural values in the United States, as opposed to their homeland, where Lithuanians' freedom was restricted by the partitioning powers - Russia and Germany. Lithuanian Americans' unrelenting efforts and patriotism led to their integration and involvement in Lithuanian business, cultural, and political affairs in the United States. One of their major successes was their contribution to Lithuanian state recognition by the U.S. government in 1922.

It is hard to find any literature about Lithuanian immigrants in the USA until the middle of the nineteenth century. It is worth mentioning Carolius Kursius, known as Alexander Carolus Curtius or Aleksander Kurcjusz-Kurczewski, who arrived from Lithuania and settled in North America, New Amsterdam - today's New York. He came to North America in 1659 and was a teacher of the Latin language $^{3}$. He was the founder of the second Latin School in America after Harvard ${ }^{4}$ As a matter of fact, Carolius Kursius is considered by Lithuanian Americans as Lithuanian and by Polish Americans as Polish.

The largest number of Lithuanian immigrants arrived in the United States in the second half of the nineteenth and at the beginning of the twentieth century, when it became one of the most popular destinations for Lithuanian immigrants ${ }^{5}$. Different factors contributed to Lithuanian migration in the second half of the nineteenth century. The immigrants were mostly young and adult men, many of whom were illiterate. The first numerous groups of Lithuanians began to arrive in the 1860s because of the enfranchisement and personal freedom granted to Lithuanian peasants by the Russian Tsar in 1863 . The rich peasants could buy more land. In contrast, numerous Lithuanian peasants could not afford to buy land, were left landless, could not find jobs and emigrated abroad. According to historian Jerzy Ochmański, there were about 400,000 unemployed Lithuanians, mainly from villages, by 1890. Many of them immigrated to the United States 6 . Their situation was further exacerbated in their homeland by intensive Russification in the second

\footnotetext{
3 G. Hartman, The Immigrant as Diplomat, Ethnicity, Nationalism, and the Shaping of Foreign Policy in the Lithuanian-American Community, 1870 - 1922, Chicago 2002, p. 27.

4 A. Brożek, Polonia amerykańska 1854-1939, Warszawa 1977, p. 10.

5 A. Eidintas, A. Bumblauskas, A. Kulakauskas, M. Tamošaitis, Historia Litwy, Wilno 2013, p. 135.

6 J. Ochmański, op. cit., p. 212.
} 
half of the nineteenth century. Church properties were confiscated, gatherings were prohibited, and Lithuanian organisations could not be established ${ }^{7}$. In 1865, Russian authorities issued a law prohibiting printing in the Lithuanian and Polish languages. Consequently, any books or writings could be printed only in Russian. It replaced Lithuanian in all public and parochial schools. Lithuanians, especially the clergy, opposed Russification. Lithuanian priests were particularly engaged in the spreading of the Lithuanian language because they opposed the Russian Orthodox Church, which was actively involved in limiting the influence of the Catholic religion in the Russian empire. Lithuanians boycotted books printed in Russian and supported the popularity of books printed in Lithuanian in East Prussia. They also supported the secret teaching of children in Lithuanian, instead of sending them to Russian schools ${ }^{8}$. Further causes that contributed to Lithuanian migration to the US was a severe famine in their homeland between 1867 and 1868 and compulsory military service for all Lithuanian men over the age of twenty-one. Lithuanians preferred to emigrate rather than to be conscripted into the Russian army. It was also easier for Lithuanians to emigrate to other countries, including the United States, due to the rapid development of their homeland. For example, in the 1860s and 1870s, a railway track connecting St. Petersburg, Vilnius, Warsaw and later Kaunas and Königsberg was built. Steamboats started to cruise the Nemunas River9. Those means of transport helped Lithuanian immigrants move to other countries quicker and cheaper. The majority of Lithuanian immigrants were attracted by job opportunities available in the US industrialised areas. It must be mentioned that the United States, like other European countries, started to develop economically in an unprecedented way in the second half of the nineteenth century. This was because goods were produced on a mass scale in connection with the development of machines and technology. Mass production drew thousands of Americans and immigrants to industrialised areas, where they could find jobs. With the advancement of the economy and increasing migration of people, different means of transport developed. Railway tracks were being built across the United States. As a consequence, it was easier and cheaper to move to other areas of the United States. Ships were being modernised and built in increasing numbers. Therefore, immigrants could travel quicker and cheaper in increasing numbers. The immigrants who stayed in the United States formed so-called chain and illegal migration. They often sent tickets, money, and invitations to their friends and relatives living in their homeland ${ }^{10}$. They were also often the sponsors of Lithuanian

7 C. R. Jurgela, Lithuania and the United States: the Establishment of State Relations, Chicago 1985, pp. 16-17.

8 J. Ochmański, op. cit., pp. 216-217.

9 A. Eidintas, A. Bumblauskas, A. Kulakauskas, M. Tamošaitis, op. cit., pp. 134-135.

10 G. Hartman, op. cit., pp. 29-30. 
immigrants, who were frequently provided with accommodation and employment in the US. On the other hand, those who did not receive support from abroad often sold all their possessions to buy tickets for travelling to the new American land. The tide of immigrants increased and reached its peak at the end of the nineteenth century, when economic conditions in the Lithuanian homeland sharply deteriorated, e.g. farmers had difficulties in finding markets abroad ${ }^{11}$. It is estimated that Lithuania lost about twenty percent of its three million population on account of migration to North America until 1914 ${ }^{12}$.

Lithuanians migrating to the United States in the second half of the nineteenth century often did not plan to remain permanently in the US and become Americanised. Instead, their intent was to live in the US temporarily, work hard, earn money, and wait for the right opportunity to return to their homeland, where they would mainly work as farmers ${ }^{13}$. Lithuanian emigration to the United States was primarily associated with the bad economic and political situation in their homeland. A small number of Lithuanians wanted to buy land in the US even though most of them had farming backgrounds in their homeland. Living on the farm required large investments of money, a long stay in the US and a risky venture due to their previous bad experiences in their homeland partitioned by Russia and German Reich, where agricultural work was associated with high taxes and hard work ${ }^{14}$.

As Alfred Erich Senn and Alfonsas Eidintas describe, about 46,000 Lithuanians immigrants migrated back to their homeland between 1898 and $1914^{15}$. They went back home because they had earned enough money to return to their homeland, where the situation was slightly improving. For example, Russian authorities lifted the ban on the Lithuanian press in 1904, and the reforms introduced by Russians after the 1905 Revolution enabled Lithuanians to expand their cultural life and organise their own schools ${ }^{16}$. Furthermore, in 1913, the Russian government offered amnesty to those who had fled Russia to avoid enlistment into the Russian army. The amnesty covered those immigrants who would return to Russia until 21 February 1914. Latecomers would face harsh penalties for evading military service ${ }^{17}$.

\footnotetext{
11 J. S. Roucek, op. cit., p. 448.

12 G. Hartman, op. cit., p. 28.

13 V. R. Greene, op. cit., p. 20

14 J. S. Roucek, Lithuanian Immigrants in Lithuania, [in:] American Journal of Sociology, Vol. 41, No. 4 (January 1936), Chicago 1936, p. 449.
}

15 Alfred Erich Senn and Alfonsas Eidintas "Lithuanian Immigrants in America and the Lithuanian National Movement before 1914" [in:] Journal of American Ethnic History, Vol. 6, No. 2, Spring 1987, p. 15.

16 Ibidem, p. 11.

17 Ibidem, p. 14. 
The Lithuanians were discouraged by notable Lithuanian patriots from staying permanently or even migrating to the US. For example, Juozas Tumas Vaizgantas, a well-known Lithuanian writer and priest who went to the United States to raise money for a teacher's college in Kaunas, claimed that the skills of Lithuanians were needed more at home than in the United States. In his opinion, Lithuanians in the United States were being exploited and had no chance of accumulating large sums of money, lived in unhealthy urban conditions and quickly forgot the Lithuanian language ${ }^{18}$. Another notable Lithuanian patriot who visited the US and criticised the Lithuanians' migration was Jonas Basanavicius, often called the patriarch of the Lithuanian nation. In his opinion, Lithuanian Americans had problems with drinking alcohol and tended to forget about their homeland. He also thought that the immigrants should support their homeland financially. Jurgis Juozas Matulaitis, later appointed the bishop of Vilnius and a prominent activist, also visited the United States in 1913. Although he praised Lithuanian Americans for their quick adaptation to the new environment, he criticised them for drinking alcohol, and young Lithuanian immigrants for forgetting their Lithuanian tradition, including religious customs ${ }^{19}$. The causes for the antisocial behaviour of some Lithuanians and other Eastern European immigrants were that it was hard for them to integrate with the new American society. They were far away from their families and friends. They found it difficult to live in big American cities, where they usually worked in factories and experienced unbearable working conditions. That new experience led some of them to mental stress and antisocial behaviour like drinking alcohol or criminal acts ${ }^{20}$.

One Lithuanian American newspaper called "Vienybe Lietuvininku" (the Unity of Lithuanians) encouraged Lithuanian Americans to return to their homeland as otherwise they would be living in a foreign land forever ${ }^{21}$. It is worth mentioning that many immigrants who returned to their homeland from the United States were disillusioned. They found that their life in the United States had been much better in social and economic terms. The new skills that they had learned during their migration were often not useful in their homeland. They realised that it was hard to communicate with their families, friends, or locals, who had never migrated abroad. It seemed to them that the Lithuanians in their homeland lacked the courage to face economic and cultural changes ${ }^{22}$. The number of Lithuanians who went back to the United States before 1914 has not been estimated. Furthermore, the

18 Ibidem, p. 12.

19 Ibidem, pp. 14-15.

20 V. R. Greene, op. cit., p. 29.

${ }^{21}$ Alfred Erich Senn and Alfonsas Eidintas, op. cit., pp. 12-15.

22 Ibidem, p. 15. 
immigration of Lithuanians was halted by World War I, restrictions on immigration into the United States and Lithuania's independence declared in 1918.

In 1924, Lithuania began to be reported as a separate country on the immigration list of the US Census Bureau ${ }^{23}$. In earlier years, the Bureau indicated that "it is possible that some persons born in Latvia, Estonia, or Lithuania were assigned to Russia"24. Lithuanians who came to the United States were not usually registered as Lithuanians. Lithuanian immigrants who lived in the area belonging to Russia were recorded as Russians, those who stated that they were Roman Catholics and spoke Polish were often recorded as Poles, and those who arrived from East Prussia were registered as Germans. The majority of Lithuanian immigrants arriving in the United States before World War I were illiterate. American immigration officials usually had their interpreters speaking Russian, Polish or German, who often treated Lithuanian immigrants' answers as reliable. According to sociologist Joseph Slabey Roucek, about 275,000 Lithuanians came to the United States by $1899^{25}$. Another specialist in immigration and ethnic community, Gary Hartman, states that, according to US Census Bureau estimates, 255,831 Lithuanian immigrants arrived in the United States between 1899 and $1916^{26}$. In total, according to the estimates of the Lithuanian Convention held in New York between 13 and 14 March 1918, there were about 750 thousand Lithuanians in the United States ${ }^{27}$. These figures are not accurate as those who returned to Lithuania and died were not reported in the U.S. Census and other sources.

Lithuanian immigrants settled in large cities, where they could find jobs more easily, live close to other Lithuanians or Eastern Europeans, and avoid losing their sense of national identity. Most Lithuanians settled in Illinois, New York, Massachusetts, Pennsylvania, and Maryland, where they worked predominantly as unskilled workers in such industrialised cities as Chicago, New York, Pittsburgh, Philadelphia, Boston, Cleveland, Baltimore, or Detroit. The largest number of Lithuanians settled in Chicago and New York. According to Roucek, in the period of World War I, about 80 thousand Lithuanians lived in Chicago and about 40 thousand in New York ${ }^{28}$. Fewer Lithuanians settled in the southern and western parts of the United States.

Most Lithuanians coming to the United States until World War I were farmers and labour workers. They often took any jobs available to them after arrival

23 U.S. Bureau of the Census. Historical Statistics of the United States, Colonial Times to 1970, Bicentennial Edition, Part 2. Washington, D.C. 1975, p. 98.

24 Ibidem, p.104.

25 J. S. Roucek, op. cit., p. 448.

26 G. Hartman, op. cit., p. 31.

27 T. Norus and J. Zilius, Lithuania's Case for independence, Washington D.C. 1918, p. 24.

28 C. R. Jurgela, op. cit., p. 21. 
to the United States. Lithuanian immigrants' main occupation was physical work in mines, mills, factories, oil, and sugar refineries. They worked as foundry men, textile and silk weavers, coal miners. Labour workers dreamt of entering the professional classes. Those who belonged to the middle class often set up their businesses, e.g. shops, tailoring establishments, restaurants, or building associations.

As previously mentioned, the majority of Lithuanians worked as labourers in the United States. Among them, there were successful workers. Antanas Kaztauskis describes his successful life in Chicago in his autobiography entitled "From Lithuania to the Chicago Stockyards". He writes as follows:

With more time and more money I live much better and I am very happy. So is Alexandria. She came a year ago and has learned to speak English already. Some of the women go to the big store the day they get here, when they have not enough sense to pick out the clothes that look right, but Alexandria waited three weeks till she knew, and so now she looks the finest of any woman in the district. We have four nice rooms, which she keeps very clean, and she has flowers growing in boxes in the two front windows. We do not go much to church because the church seems to be too slow. But we belong to a Lithuanian society that gives two picnics in summer and two big balls in winter, where we have a fine time. I go one night a week to the Lithuanian Concertina Club. On Sundays, we go on the trolley out into the country ${ }^{29}$.

This description presents a clear picture of what social status an ordinary Lithuanian immigrant expected to have in the United States. The Lithuanian Americans usually married their partners from the United States or their homeland, from where they invited their spouses to live in the US. They knew that quick learning of English would make their life easier as all the financial, administrative, or business matters were mainly dealt with in English. Also, they could freely share their thoughts and interests in their own Lithuanian organisations. Another important opportunity for Lithuanian Americans was that they could earn enough money in the US to buy their own flat or house. All these factors contributed to the Lithuanians' growing satisfaction with their life in the US.

However, some Lithuanian immigrants in the United States had to work hard in unpleasant conditions and were exploited by their employees. In the book entitled "The Jungle", written by Upton Sinclair in 1906, the life of Lithuanian immigrants in Chicago is presented in detail. The main character of the book is Jurgis Rudkus, a Lithuanian immigrant who experiences tough living conditions in Chicago. The book presents a harsh and unpleasant environment, the poverty and hopelessness among the Lithuanian immigrants, most of whom were employed in

\footnotetext{
29 A. Kaztauskis, From Lithuania to the Chicago Stockyards - An Autobiography [in:] Plain Folk: The Life Stories of Undistinguished Americans, eds. M. David Katzman, M. William, Jr. Tuttle, 1982, pp. 112-113.
} 
the meat-packing industry in Chicago and its neighbourhoods at the turn of the nineteenth and twentieth century.

Before World War I, Lithuanian immigrants, whose community was not populous in the United States, often settled in areas inhabited by Poles, Jews, Russians and other Eastern European ethnic communities. This was due to the fact that the Lithuanians were strongly and culturally interrelated with those communities who once were their neighbours in their homeland. Lithuanian immigrants had strong ties with the Polish community. Both communities lived close to each other, especially in Pennsylvania or Illinois, where immigrants could find jobs easier than in other parts of the United States. The ties between the Lithuanians and Polish ethnic groups were especially strong at the time when the first waves of Polish and Lithuanian immigrants arrived in the United States in the 1860s and 1870s. They cooperated because they shared the same experience in the New World and some Lithuanians spoke or understood Polish. They were usually unqualified hard-working and conscientious workers who had agricultural backgrounds, no experience in doing business and were eager to have their own land ${ }^{30}$. Their need to buy or own land, and their peasant background is reflected in their way of life in the United States. While working in urban centres, Poles and Lithuanians often cultivated the agrarian values inherited from their homeland. For example, they raised livestock or grew vegetables next to their homes. Furthermore, they sent considerable sums of money to their relatives living in Czarist Russia to buy farmland or buildings, or invested in property in their new American homeland. In Victor Greene's opinion "immigrants were achieving a modified realization of the old peasant dream"

Lithuanian and Polish immigrants created loan societies, which supported them in times of urgent situations like deaths, accidents or sicknesses. They made contributions and, in return, were provided with minimum social care. Also, the loan societies helped them to accumulate money to buy houses or land. The Polish and Lithuanian investors were mainly those who considered a permanent stay in the United States. The number of houses and land purchased by Poles and Lithuanians in the United States was impressive at the beginning of the $20^{\text {th }}$ century. It was because they had a characteristic quality to acquire property or farmland brought from their homeland ${ }^{32}$.

Lithuanians shared the same religion and the Polish language, which was spoken as a second language by the majority of Lithuanian immigrants. Furthermore, Lithuanian and Polish immigrants had a mutual history as their predecessors had lived in the Polish-Lithuanian Commonwealth before it was partitioned in the second half of the $18^{\text {th }}$ century, and they shared their anti-Russian attitudes

\footnotetext{
$30 \quad$ V. R. Greene, op. cit., p. 27.

$31 \quad$ Ibidem, p. 37.

32 Ibidem, pp. 39-42.
} 
mainly because of the partitions of Poland and Lithuania. They together set up community centres, associations, parishes or had joint businesses, and established a Club of Polish-Lithuanian Friendship and the Adam Mickiewicz Polish-Lithuanian Society ${ }^{33}$.

This situation began to change with the increase of the number of Lithuanian immigrants at the turn of the nineteenth and twentieth century. Lithuanian Americans, especially those from the middle class, were more inclined to nurture the tradition of Lithuanians, including the Lithuanian language. They feared to lose their sense of identity, especially in the Polish community. Also, Lithuanian American community leaders strongly advocated separation from the Polish community ${ }^{34}$. Anti-Polishness was to raise Lithuanian American cultural group consciousness. Disputes between the two ethnic groups began to arise. Their misunderstandings concerned mainly the prevailing languages for sermons, prayers, and songs at churches and parish meetings and over who should control parishes or be appointed as a priest ${ }^{35}$.

Lithuanian Americans attached great importance to the language of masses held in their churches. Similar tendencies could be observed in the Lithuanians' native land. As opposition to Russification grew in partitioned Lithuania and Lithuanians started to be more aware of their self-identity by the end of the nineteenth century, Lithuanians more eagerly sought to replace the Polish language with Lithuanian, particularly in churches and parishes. This process was greatly intensified by the Lithuanian press - mostly printed in the East Prussia - and the Lithuanian clergy $^{36}$.

Other misunderstandings concerned political affairs. Many American-Lithuanians thought that Lithuania should be independent and not unified with Poland, unlike before the partitions of the Polish-Lithuanian territories. Therefore, Lithuanian-American society thought that cooperation with Poles was contrary to their patriotic ideas about their independent nation. As the Lithuanians started to be more aware of their self- identity, they created or used their typical Lithuanian names and surnames ${ }^{37}$. Such tendencies were not only prevalent in Lithuanian American society. There were massive waves of immigrants arriving from other areas of Europe to the United States at the turn of the nineteenth and twentieth

\footnotetext{
33 M. Runiewicz, Wspótpraca Litwinów i Polaków w Stanach Zjednoczonych w przekroju historycznym, [in:] International Journal of Management and Economics 13 (2002), Warszawa 2001, pp. 180-182.
}

34 W. Wolkovich-Valkavicius, Religious Separatism among Lithuanian Immigrants in the United States and their Polish Affiliation, Polish American Studies, Vol. 40, No. 2, Autumn 1983, pp. 120-121.
35 A. Brożek, op. cit., p.97.
36 J. Ochmański, op. cit,, p. 241.
37 G. Hartman, op. cit., pp. 33-36. 
century. They were often eager to focus on their cultural identity having such opportunities in the United States as freedom of the press, religion or language ${ }^{38}$.

Jewish emigration from the Russian empire to the United States was also significant before World War I. It is estimated that, between 1880 and 1914, about 1.6 million Jews emigrated to the United States from the Russian empire, also from its Lithuanian territories ${ }^{39}$. Jews had few social and economic expectations about their future prospects in the Russian empire. Their concerns about their fate in the Russian empire were raised because of the 1881-1882 and later period pogroms in the Ukrainian and Polish provinces of Russia, possible persecution, and the negative attitude of local inhabitants ${ }^{40}$.

It should be mentioned that Jews were particularly involved in developing illegal routes of emigration in the Russian empire and Germany. Emigration from the Lithuanian territories of the Russian Empire was facilitated by the development of the following railway routes: St. Petersburg - Vilnius - Warsaw (built in 1862), Libava - Shavli - Romny (built in 1873) and Tilsit - Bajori - Memel (built in 1875) ${ }^{41}$. Emigrants used such routes to travel to the two main German ports of Hamburg and Bremen, from where they could travel by ship to the United States. Jews dominated the business of chain migration from the Lithuanian territories to Germany. Most of them were literate, spoke better German, and had numerous contacts with German officials and steamship companies.

After arrival in the United States, the majority of Jewish immigrants, as compared to Lithuanians, were more inclined to stay permanently in the United States because they had skilled occupations. In the period of 1899-1910, 76 per cent of Lithuanian immigrants to the United States claimed that they were unskilled workers. In comparison, Jews emigrating to the United States in the above period constituted almost 63 per cent of skilled workers, mainly carpenters, shoe-makers, or tailors. Having such skills, it was easier for Jews to find employment in the United States. Furthermore, contrary to Lithuanian emigrants, more Jewish females left for the United States. Therefore, Jews were inclined to stay and set up families in the new foreign land, having no close family ties in their former homeland. The above circumstances encouraged vast numbers of Jewish immigrants to stay in the United States permanently. Jews had the lowest level of return from among all Russian emigrant groups ${ }^{42}$.

\footnotetext{
38 M. Runiewicz, op. cit., p. 182.

39 T. Balkelis, Opening Gates to the West: Lithuanian and Jewish Migrations from the Lithuanian Provinces, 1867-1914, Ethnicity Studies 2010/1-2, Vilnius 2010, p. 55.

$40 \quad$ Ibidem, pp. 54-56.

41 Ibidem, p. 58.

42 Ibidem, p. 56.
} 
Cultural and educational involvement played a significant role in building a strong Lithuanian community in the United States. Like other ethnic communities in the United States, Lithuanian Americans participated in social activities through social, literary, religious, educational or cooperative organisations. Such activities usually contributed to the increasing awareness of Lithuanian national identity. Lithuanian Americans' level of nationalism, usually among the working class, was gradually increasing owing to tiny groups of educated Lithuanians. As Victor Greene mentions "they were an elite segment, tiny in number, primarily refugee intellectuals [...]. This handful of ethnic patriots worked enthusiastically to perpetuate their nation's name" ${ }^{43}$. Lithuanian Americans attended Lithuanian and English language classes. Most importantly, they used their mother tongue. Lithuanians married within their community and went to Lithuanian churches or attended meetings at their parishes to avoid losing their sense of national identity. At such places, the Lithuanian patriotic groups were established. There were Lithuanian organisations in almost every state inhabited by groups of Lithuanians. Some of them are listed by Joseph Slabey Roucek:

The Lithuanian Patriotic Society is devoted chiefly to educational purposes. There are, in addition to seventeen additional national societies, numerous local societies and clubs. There is a Lithuanian Medical Association, a Lithuanian Pharmaceutical Association, a Lith-American University Association, a Labor Association, the Lithuanian Labor Association , the Lithuanian Roman Catholic Women's Association, the Lithuanian Women's Association, the Knights of Lithuania (comparable to the Knights of Columbus), the Lithuanian Literary Association, the Lithuanian Lawyers' Association, and others ${ }^{44}$.

Such organisations wanted, through religious, social and literary activities, to imitate social institutions once existing in their homeland. According to Antanas Kaztauskis, "You can read free papers and prayer books. In Chicago, there are prayer books for every man and woman. You can have free meetings and talk out what you think" ${ }^{45}$. Most Lithuanians were Catholics. Therefore, they wanted to have Lithuanian priests celebrating masses in Lithuanian. Lithuanian social activities often included literature, drama, painting and other forms of art. Lithuanian folk groups and ensembles were established. On numerous occasions, particularly during Lithuanian festivals, the community met to exchange their views on social affairs, an independent Lithuania, as well as to read patriotic literature or participate in traditional dances ${ }^{46}$.

\footnotetext{
43 V. R. Greene, op. cit., p. 4.

44 J. S. Roucek, op. cit., pp. 450-451.

45 R. Kaztauskis, op. cit., p. 103.

46 J. S. Roucek, op. cit., pp. 450-452.
} 
The Lithuanian community focused on the promotion of Lithuanian affairs in the media. Therefore, numerous newspapers magazines and books were published in English and Lithuanian. The first Lithuanian newspaper published in the United States was "The Gazieta Lietuviska" (Lithuanian Newspaper). It was first published in New York on 16 August 1879 and was written in Polish and Lithuanian. The first newspaper published in pure Lithuanian appeared in 1884 and was titled "Vienybe Lietuvininku"; later its title was changed to the "Vienybe". There were dozens of Lithuanian periodicals being published in the United States by 1918. The most popular ones were as follows: "Amerikos Lietuvis" (American Lithuania); weekly (Worcester, Mass.); "Darbininkas" (Worker), twice weekly, Christian Democrat (Boston, Mass.); "Dirva" (Field), weekly, non-party (Cleveland, Ohio); "Draugas" (Friend), daily, Christian Democrat (Chicago, Ill.); "Garsas" (Sound), weekly, Christian Democrat (Brooklyn, NY); "Keleivis" (Traveler), weekly, Social Democrat" (Boston, Mass.); "Laisve" (Freedom), daily, Communist (Brooklyn, NY); "Naujienos" (News), daily, Social Democrat (Chicago, Ill.); "Sandara" (Concord), weekly (Boston, Mass.); "Saule" (Sun), twice weekly, non-party (Mahanoy City, Pa.); "Tevyne" (Fatherland), weekly, non-party (New York, NY); and "Vienybe" (Unity), twice weekly, non-party (Brooklyn, NY) ${ }^{47}$. Most of these magazines were written in English and Lithuanian. The articles mostly presented the everyday life of Lithuanian Americans, their meetings, political organisations, economic issues and the history of Lithuania. Many of those magazines and books were sent to Lithuanians living in the partitioned homeland. Lithuanian Americans, among others, tried to improve their image in articles in the American press if they were viewed in a negative light. For example, in 1898, Lithuanians organised a meeting attended by more than 2,000 supporters of Lithuania in response to an article published in the Chicago-based "Evening Journal", which presented Lithuanians as uneducated and not well-mannered. Their protest was spotted by the press in Chicago, which described Lithuanians as a community with a high personal culture ${ }^{48}$.

There were numerous Lithuanian political organisations established in the United States. The main ones included Catholics, socialists and nationalists. One of the most famous Lithuanian social democrats who immigrated to the United States was Jonas Sliupas. He studied at the Moscow, St. Petersburg and Geneva universities, immigrated to the United States in 1884 and graduated from medical school at the University of Maryland in 1891 . He was known as a writer, politician, and activist propagating the Lithuanian national revival, as well as an opponent of the Catholic Church. In the United States, he was engaged in activities that promoted an independent Lithuania and was the editor of numerous publications about Lithuanian culture. Jonas Sliupas mainly emphasised the fact that the Lithuanian

47 Ibidem, p. 453.

48 G. Hartman, op. cit., p. 75. 
community should form a separate community with its own language and culture. He published books about Lithuanians' oppression in their homeland. One of Sliupa's books is entitled "The Bestiality of the Russian Czardom toward Lithuania". In this book, Jonas Sliupas presented in detail the repression of Lithuanians inflicted by Russian occupiers. The intention of the author was to explain the mass number of Lithuanian immigrants coming to the United States from the partitioned Lithuania. According to the author, the popularisation of Lithuanian immigrants in the United States meant a better understanding of the situation of Lithuanians in American society as well as the American government ${ }^{49}$.

Jonas Sliupas organised one of the first major meetings of Lithuanian Americans in Shenandoah, Pennsylvania, where the "Alliance of All Lithuanians of America" was established on 15 August 1886. The primary task of the Alliance was to promote the Lithuanian language among Lithuanian immigrants and schools in the United States. Furthermore, the Alliance tried to find employment for new immigrants from Lithuania. Lithuanian clerics, as opposed to the nationalists and socialists, formed their own organisation in Plymouth, Pennsylvania, 22 November 1886 called the "Alliance of all Lithuanian Catholic Societies of America". The two alliances worked together by supporting Lithuanian identity among the American Lithuanians. The above alliances also intensified their efforts to eliminate Polish and Russian cultural influence on Lithuanian immigrants. In 1889, the two alliances merged to form the "Lithuanian Alliance of America". Disagreements between socialists, nationalists and clerics eventually led to the separation of the clerics, who created the "Lithuanian Roman Catholic Alliance of America" in 1901. The socialists and nationalists remained within the "Lithuanian Alliance of America" and cooperated ${ }^{50}$.

With the outbreak of World War I, the "Lithuanian Alliance of America" and the "Lithuanian Roman Catholic Alliance of America" began to cooperate more closely. The two Alliances believed that Russia would disintegrate, and Lithuania should be independent. As a result, the two Alliances organised a convention in Chicago on 21 and 22 September 1914, during which they created the "National Council of Lithuania" ${ }^{51}$ which collected funds for war victims and promoted the aspirations of Lithuanian for their own independent country.

The first major joint success of nationalists and clericalists was that they managed to convince some U.S. congressmen to request President Wilson to create a special fund for war victims in Lithuania in 1916. The President's adoption of the fund encouraged Lithuanians in America to lobby the U.S. government more

\footnotetext{
49 Ibidem, pp. 47-56.

$50 \quad$ Ibidem, pp. 172-174.

51 C. R. Jurgela, op. cit., p.48.
} 
actively for the purpose of recognizing Lithuania's independence ${ }^{52}$. Leaflets, books and guides to historic Lithuania were widely distributed in the United States. Lithuanian immigrants in the United States were engaged in the support for Lithuanians occupied by Germans, i.e. they sent food and medicine supplies. Furthermore, numerous Lithuanian immigrants declared their readiness to return to Lithuania to take up the fight for independence.

At the time of World War I, differences between the socialists and nationalists deepened. The first was rather focused on supporting the Lithuanian working class, which, they believed, could strengthen cooperation with workers from Russia and Germany. Moreover, they were more interested in general socialist movements rather than independent Lithuania. The socialists focused on providing financial support to socialist groups operating in Lithuania. After the Bolshevik Revolution in 1917, socialists wanted to establish closer cooperation with the Bolsheviks as well as promote universal socialist ideas in Lithuania and oust the monarchy from power $^{53}$.

At the turn of 1917-1918, in the United States, Lithuanians especially the nationalist and clerical Lithuanian Council started to speak with one voice because of the changing situation in Lithuania. The abdication of the Russian Tsar Nicholas II, the establishment of the Russian Provisional government in March 1917, the Russian October Revolution in 1917, the establishment of Taryba in Lithuania under German rule in September 1917 and hopes for US support strengthened the Lithuanian Americans' efforts to have an autonomous or even independent Lithuania.

It should be mentioned that Lithuanians' hopes for US support mainly arose out of President Wilson's XIV points announced in January 1918, favouring self-determination of all peoples. Lithuanians were particularly interested in Points VI and XIII because those points referred to Russian territorial issues and Poland's independence. Point VI states as follows:

The evacuation of all Russian territory and such a settlement of all questions affecting Russia as will secure the best and freest cooperation of the other nations of the world in obtaining for her an unhampered and unembarrassed opportunity for the independent determination of her own political development and national policy and assure her of a sincere welcome into the society of free nations under institutions of her own choosing; and, more than a welcome, assistance also of every kind that she may need and may herself desire. The treatment accorded Russia by her sister nations in the months to come will be the acid test of their goodwill, of their comprehension of her needs as distinguished from their own interests, and of their intelligent and unselfish sympathy ${ }^{54}$.

\footnotetext{
52 G. Hartman, op. cit., pp.178-179.

53 Ibidem, p. 172.

54 President Wilson's State Papers and Addresses, ed. A. Shaw, New York 1918, pp. 468-469.
} 
The question here is what is meant by Russian territory. This issue seems to be portrayed by Point XIII, which states as follows:

An independent Polish state should be erected which should include the territories inhabited by indisputably Polish populations, which should be assured a free and secure access to the sea, and whose political and economic independence and territorial integrity should be guaranteed by international covenants ${ }^{55}$.

It can be inferred from Point XIII that granting recognition to partitioned Poland, should involve granting independence to other areas partitioned by Russia, inhabited by the Finns, Estonians, Letts, Lithuanians or Ukrainians. Otherwise, as Edward Mandell House, a key advisor to President Woodrow Wilson, thought, it would be hypocritical to recognise only one former Russian province ${ }^{56}$ and would be contrary to President Wilson's call in Point XIV for "affording mutual guarantees of political independence and territorial integrity to great and small [states] alike ${ }^{57}$. This point of view was shared by many Lithuanian Americans, who saw in Wilson's points an opportunity for establishing and recognising an independent Lithuania $^{58}$.

After Lithuania's declaration of independence on 16 February 1918, more than one thousand Lithuanian delegates organised a meeting in New York at Madison Square Garden on 13-14 March 1918. The participants of the Convention, including mainly Lithuanian clerics and nationalists, supported an independent Lithuania and wanted it to be officially recognised by all nations and organisations. During the Convention, the Lithuanians also decided to establish a new representative body in the United States called the Executive Committee, whose role was to represent the secular and clerical "Lithuanian National Councils" in the United States. The establishment of the Executive Committee took place on 29 October 1918. ${ }^{59}$. The primary task of the Committee and the Lithuanian American community in the United States was to win Lithuania's recognition by the U.S. Administration in the near future. Lithuanian Americans' efforts, supported by an independent Lithuanian government, ended in success when Lithuania was recognised by the U.S. government as an independent state in 1922.

It must be said that Lithuanian Americans were strongly integrated in the United Stated owing to their self-identity, increased by freedom of speech, religion,

\footnotetext{
Ibidem, p. 470.

G. Hartman, op. cit., p. 133.

A. Shaw, ed., op. cit. p. 470.

58 G. Hartman, op. cit., pp. 133-134.

59 C. R. Jurgela, op. cit., pp. 80-81.
} 
and thought in the United States ${ }^{60}$. Having no cultural and political restrictions in the new American land, in contrast to their partitioned homeland, Lithuanian Americans were free to set up their political and cultural organisations, attend masses held in their native language and speak their mother tongue. Furthermore, they were encouraged to increase their self-identity owing to other integrating ethnic groups in the United States, which spoke their own languages, cultivated their traditions and customs, as well as faced similar hardships in the new land. The United States offered Lithuanian immigrants new perspectives also owing to the industrial revolution in the United States. Lithuanian Americans worked mainly in industrialised areas. They were not discouraged by their exploitation at work, the language barrier, and hard-working conditions as they earned decent money to buy property and other things of which they could only dream in their distant homeland. They knew that the situation in their native land was much worse in economic and political terms. It was easier for the immigrants to find a job and more convenient to live in the United States also because they often stayed close to the immigrant communities, mainly from Central and Eastern Europe, which spoke a similar language, shared a similar religion and other cultural values, as well as had comparable political backgrounds. The immigrants from the partitioned countries were particularly engaged in developing their strong community and identity as they were driven by their need to be independent. Consequently, they felt that they were closer to their homeland in such communities. As Victor Greene quotes: "It was the realization of this common cultural conflict that taught the East Europeans that they were members of a nationality [...]. They realized their own distinctive culture by confronting an alien one" 61 .

The above examples explain why the tide of immigrants from Central and Eastern Europe to the United States sharply increased before World War I. However, the similarities mentioned above did not mean that the Lithuanian Americans had good cooperation with all immigrants from Central and Eastern Europe. For example, the first American Lithuanian groups arriving to the United States in the 1860s and 1870s had a good relationship with the Polish American Community in the United States mainly because of the same Catholic religion and opportunity to communicate in Polish. With the lapse of time, it changed. Lithuanian Americans started to distance themselves from the Polish community because they thought that their cultural values, especially their language, could be replaced by Polish culture. The animosities had their roots in their homeland, where the Lithuanians did not want the Polish to popularise their own language or to interfere with the

60 W. Wolkovich-Valkavicius, Immigrants who became Lithuanian by becoming American, "Lituanus, Lithuanian Quartely Journal of Arts and Sciences", Volume 40, No.2, ed. Robert A. Vitas, Summer 1994.

${ }^{61}$ V. R. Greene, op. cit., pp. 29-30. 
affairs of future Lithuania for the purpose of being independent of Polish influence in cultural, economic, and political terms. It must be further stated that during the World War I period, Lithuanian Americans' integration in the United States strengthened as they hoped that their native land could be independent by the end of the war. Consequently, they lobbied the US government and the public in favour of Lithuania's independence and raised money for the Lithuanian cause. However, not all the Lithuanian political groups were united in their view of a future independent Lithuania. The differences among Lithuanian political organisations increased especially when World War I was coming to an end. Lithuanian socialists must be mentioned here. They focused on supporting a socialist Lithuania, united with other socialist countries, including Soviet Russia. Other groups supported German rule when the Germans occupied Lithuania between 1915 and 1918. Finally, it must be said that the majority of Lithuanian Americans in the United States supported Lithuania as a sovereign state, uninfluenced by any foreign powers and co-existing on equal terms with other European countries. The Lithuanian Americans' political, social and financial efforts were successful when Lithuania was declared independent on 16 February 1918, was granted recognition by the government of the United States in 1922, and finally was considered as a separate Lithuanian ethnic community.

\section{Lithuanians in the United States at the turn of the 19th and 20th centuries}

\section{Summary}

At the turn of the 19th and 20th centuries, the United States was one of the most popular destinations for emigrants from the Lithuanian territories in the Russian Empire. They emigrated because they had no economic, social, or political perspectives in their homeland, which was part of the Russian Empire and the German Reich until 1918, when Lithuania proclaimed to be independent. The Lithuanians living in the Russian Empire were subjected to persecution as they were forbidden to speak their mother tongue or learn about their native history or culture. Moreover, they could not afford to buy land and were left landless and jobless mainly because of the unfavorable Russian policy to russify and economically exploit the areas controlled by the Tsar.

In the pre-World War I period, the United States was a favourable country for Lithuanian emigrants because they could enjoy economic, social, and political freedom in that country. They could earn enough money to support their families left behind in their homeland, which often followed their relatives or friends living in the new land. It was much easier for them to find a job in the United States, where the Industrial Revolution created a massive demand for new workers. Lithuanian 
Americans lived next to other ethnic communities, which could unrestrictedly speak their native language, profess their own religion, learn about their history, establish their own political organisations, as well as issue their own newspapers or books. Such freedom encouraged American Lithuanians to integrate within their own community and to take advantage of opportunities they had never had in their homeland. As the United States was such an attractive place for the newcomers, the number of Lithuanians leaving the Russian Empire increased sharply. This was possible mainly because new railway lines were built in the Russian Empire, including the Lithuanian areas. Such routes led to ports in Germany, from where the emigrants sailed to the United States. Before World War I, hundreds of thousands of Lithuanian emigrants arrived in the United States to start their new lives.

It must be said that Lithuanian Americans were successful as an ethnic community in the United States. They were strongly integrated. They cultivated their cultural values and sent money to their families in the United States and their relatives living in the Russian Empire. Lithuanian Americans established their own political organisations, which lobbied the US government as well as other political and economic organisations to support an independent Lithuania, contributed to the establishment of a Lithuanian mission in Washington D.C. and recognition of Lithuania by the US government as an independent state on 28 July 1922. The economic and social perspectives in the United Stated encouraged most Lithuanian emigrants to stay in the United States permanently, even when Lithuania became independent in 1918, and its inhabitants were no longer persecuted because of their ethnic origin.

Key words: Lithuanian, American, Russian, immigrants, homeland

\section{Litwini w Stanach Zjednoczonych Ameryki na przełomie XIX i XX wieku}

\section{Streszczenie}

Na przełomie XIX i XX stulecia Stany Zjednoczone były jednym z najbardziej popularnych kierunków emigracyjnych dla ludności z terytoriów litewskich w Imperium Rosyjskim. Emigracja z tych terenów była popularna w tamtym czasie, ponieważ osoby emigrujące nie miały perspektyw gospodarczych, społecznych ani politycznych na swojej ziemi ojczystej, kontrolowanej przez Imperium Rosyjskie i Rzeszę Niemiecką do 1918 r., kiedy Litwa ogłosiła niepodległość. Litwini żyjący w Imperium Rosyjskim byli poddawani prześladowaniom, ponieważ zabraniano im porozumiewania się w języku ojczystym, uczenia się ojczystej historii lub kultury, oraz nie było ich stać na zakup ziemi i wielu z nich skazanych było na bezrobocie, głównie ze względu na niekorzystną politykę rosyjską polegającą na 
rusyfikacji i czerpaniu korzyści gospodarczych na terenach kontrolowanych przez cara.

Przed I wojną światową, Stany Zjednoczone były bardzo popularnym krajem dla emigrantów litewskich, ponieważ w tym kraju mogli korzystać z wolności gospodarczej, społecznej i politycznej. Mogli zarobić wystarczająco pieniędzy dla swoich rodzin pozostawionych w ojczyźnie, którzy często podążali za ich krewnymi lub przyjaciółmi żyjącymi w nowym i dalekim kraju. Łatwiej było im znaleźć pracę w Stanach Zjednoczonych, gdzie rewolucja przemysłowa stworzyła ogromny popyt na nowych pracowników. Litwini amerykańscy mieszkali obok innych wspólnot etnicznych, które mogły bez ograniczeń porozumiewać się we własnym języku, wyznawać własną religię, poznawać własną historię, tworzyć własne organizacje polityczne, a także wydawać własne gazety lub książki. Taki rodzaj wolności zachęcał Litwinów amerykańskich do integracji we własnej społeczności i korzystania z możliwości niespotkanych w ich ojczyźnie. W związku z tym, że Stany Zjednoczone były tak atrakcyjnym krajem dla nowo przybyłych emigrantów, liczba Litwinów opuszczających rosyjskie imperium gwałtownie rosła. Było to możliwe głównie dlatego, że powstały nowe linie kolejowe w Imperium Rosyjskim, w tym na terenach litewskich, które prowadziły do portów w Niemczech, skąd emigranci płynęli do Stanów Zjednoczonych. Do wybuchu I wojny światowej setki tysięcy litewskich emigrantów przybyło do Stanów Zjednoczonych, aby rozpocząć nowe życie.

Można stwierdzić, że Litwini amerykańscy odnieśli sukces jako społeczność etniczna w Stanach Zjednoczonych. Byli silnie zintegrowani. Pielęgnowali ojczystą kulturę i przekazywali zarobione pieniądze dla swoich rodzin w Stanach Zjednoczonych i krewnych żyjących w Imperium Rosyjskim. Litwini amerykańscy założyli również własne organizacje polityczne, które lobbowały rząd USA oraz inne organizacje polityczne i gospodarcze w celu wsparcia niezależnej Litwy, co w późniejszym okresie przyczyniło się do ustanowienia litewskiego przedstawicielstwa w Waszyngtonie i w końcu uznania Litwy przez rząd Stanów Zjednoczonych, jako niezależnego państwa 28 lipca 1922 r. Perspektywy ekonomiczne i społeczne w Zjednoczonym Stanowisku sprawiły, że większość emigrantów litewskich zdecydowały się na stały pobyt w Stanach Zjednoczonych, nawet gdy Litwa stała się niezależna w 1918 r., a jej mieszkańcy nie byli już prześladowani z powodu ich etnicznego pochodzenia.

Słowa kluczowe: Litwini, Amerykanie, Rosjanie, emigranci, ojczyzna 


\section{Bibliography}

\section{Primary Sources}

U.S. Bureau of the Census. Historical Statistics of the United States, Colonial Times to 1970, Bicentennial Edition, Part 2. Washington, D.C. 1975.

Kaztauskis A., From Lithuania to the Chicago Stockyards-An Autobiography [in:] Plain Folk: The Life Stories of Undistinguished Americans, eds. M. David Katzman, M. William, Jr. Tuttle, 1982,

Sliupas J., Lithuania in Retrospect and Prospect, New York 1915.

Sliupas J., Burba A., Bestiality of the Russian Czardom toward Lithuania, Baltimore 1891.

\section{Secondary Sources}

Balkelis T., Opening Gates to the West: Lithuanian and Jewish Migrations from the Lithuanian Provinces, 1867-1914, Ethnicity Studies 2010/1-2, Vilnius 2010.

Lithuania: Facts Supporting Her Claim for Re-establishment as an Independent Nation, ed. J. J. Bielskis, Washington D.C. 1918.

Brożek A., Polonia amerykańska 1854-1939, Interpress, Warszawa 1977.

Eidintas A., Bumblauskas A., Kulakauskas A., Tamošaitis M., Historia Litwy, Wilno 2013.

Alfred Erich Senn and Alfonsas Eidintas, "Lithuanian Immigrants in America and the Lithuanian National Movement before 1914" [in:] Journal of American Ethnic History, Vol. 6, No. 2 (Spring 1987).

Greene V. R., For God and Country: the Rise of Polish and Lithuanian Ethnic Consciousness in America, 1860-1910. Madison: State Historical Society of Wisconsin, 1975.

Hartman G., The Immigrant as Diplomat, Ethnicity, Nationalism, and the Shaping of Foreign Policy in the Lithuanian-American Community, 1870-1922, Chicago 2002.

Jurgela C. R., Lithuania and the United States: the Establishment of State Relations, 1985.

Norus T., Zilius J., Lithuania's Case for Independence, Washington D.C. 1918.

Ochmański J., Historia Litwy, Ossolineum 1990

Roucek J. S., Lithuanian Immigrants in Lithuania, [in:] American Journal of Sociology, Vol. 41, No. 4, January 1936.

Runiewicz M., Wspótpraca Litwinów i Polaków w Stanach Zjednoczonych w przekroju historycznym, [in:] International Journal of Management and Economics 13 (2002), Warszawa 2001.

President Wilson's state papers and addresses. ed. A. Shaw, New York 1918.

Van Reenan A. J., Lithuanian Diaspora: Konigsberg to Chicago: Lanham, New York, London 1990. 
Wolkovich-Valkavicius W., Immigrants who became Lithuanian by becoming American, [in] Lituanus, Lithuanian Quartely Journal of Arts and Sciences, Volume 40, No. 2, Summer 1994, ed. Robert A. Vitas.

Wolkovich-Valkavicius W., Religious Separatism among Lithuanian Immigrants in the United States and their Polish Affiliation, Polish American Studies, Vol. 40, No. 2 , Autumn 1983.

Wolkovich-Valkavičius W., Tensions in Bi-Ethnic Parishes: Poles and Lithuanians in New England, Polish American Studies, Vol. 58, No. 2, Autumn 2001. 